\title{
AN ANALYSIS OF GUIDED PEER REVIEW TO IMPROVE WRITING SKILL ON PERSONAL RECOUNT TEXTS FOR HIGH SCHOOL STUDENTS IN BOJONEGORO
}

\author{
Mohammad Fatoni ${ }^{1}$, Ahmad Tauchid ${ }^{2}$ \\ ${ }^{1,2}$ Program Studi Pendidikan Bahasa Inggris, Universitas Nahdlatul Ulama Sunan Giri \\ email: mohammadfatoni@unugiri.ac.id \\ email: ahmadtauchid@unugiri.ac.id
}

\begin{abstract}
This research aims to analyze guided peer review to improve writing skill on personal recount texts for high school students in Bojonegoro in the aspects of (1) How is the process of implementing guided peer review (2) the students' problems in writing personal recount texts (3) how the students' writing after using guided peer review. This research uses colaborative classroom action research method. Analysis of the students' problems in composing personal recount texts is analyzed in five components of writing such as content, organization, vocabulary, languge use, and mechanics. The Results of the analysis of average scores reveal that the students have problems in all components of writing in composing personal recount text in the initial drafts of the first cycle. However, there is significant improvement on the students class mastery of final draft from the first to second cycles. They are 53\% and $83 \%$ students reach the minimum score criteria. Operational comments and suggestions help their peer to develop their writing better. It means guided peer review is able to improve the students writing skill in pesonal recount texts.
\end{abstract}

Keyword: Guided peer review, personal recount texts, writing components.

Abstrak: Penelitian ini bertujuan untuk menganalisis guided peer review untuk meningkatkan keterampilan menulis teks personal recount pada peserta didik SMA di Kabupaten Bojonegoro dalam hal (1) Bagaimana proses implementasi guided peer review (2) permasalahan peserta didik dalam menulis teks personal recount dan (3) bagaimana tulisan peserta didik setelah menggunakan guided peer review. Penelitian ini menggunakan metode penelitian tindakan kelas kolaboratif. Analisa permasalahan penulisan teks personal recount pada semua komponen keterampilan menulis antara lain isi, organisasi, kosa kata, grammar, dan mekanik. Hasil analisis dari nilai rata-rata mengungkapkan bahwa peserta didik memiliki masalah dalam semua komponen keterampilan menulis pada draf awal di siklus pertama. Namun, ada peningkatan yang signifikan pada penguasaan kemampuan menulis pada draf akhir dari siklus pertama hingga kedua sebesar $53 \%$ dan $83 \%$ peserta didik dapat mencapai nilai kriteria ketuntasan minimal (KKM). Komentar dan masukkan yang jelas membantu teman sebayanya dalam mengembangkan tulisannya lebih baik. Ini berarti guided peer review dapat meningkatkan kemampuan menulis teks personal recount peserta didik.

Kata kunci: peer review terbimbing, teks personal recount, komponen tulisan.

\section{INTRODUCTION}

Some strategic steps are being taken by the government to improve the quality of education in our country. Strategic programs that have received serious attention include improving the quality of teachers through the teacher certification program and updating the curriculum. Teachers are expected to be able to stimulate students' abilities for critical thinking and problem solving. The ultimate goal in learning English is expected that students are able to develop skills in 
understanding texts and communicating in English. This is called literacy ability that one of these skills is writing skills.

However, arranging words into writing or writing texts properly is an obstacle that is still encountered in school. They are not able to convey ideas coherently and intactly even they do not seem to have the desire to put their ideas in written form because writing is a difficult activity for them where they must be able to express opinions indirectly in the form of words. These difficulties are caused by a number of factors including inadequate teaching strategies about writing, students' vocabulary mastery, generic structure understanding, language features, and the absence of learning media about writing that support during the teaching and learning process. Among these factors, the problem that is considered the most crucial is the teaching strategy because teaching students about appropriate writing skills must be through certain approaches including the stages of writing or steps of writing, text structure or generic structure, language characteristics or language features which must be understood by students well in order to produce written texts that are appropriate and easily understood by the reader.

In fact, preliminary observations to a group of students in class $X$ or 10 show that the teacher only asks students to make written personal recount texts without sufficient knowledge and guidance from the teacher concerned how to write the right one. Then, the teacher only asked them to submit the written texts without commenting or correcting vocabulary and grammar errors. The teacher also never discusses the students' writing about errors or things that need to be developed in their writing. Learners assume there is nothing else that needs to be revised and edited against their written text because they have already got a value for the written text. In terms of assessment, the teacher assesses students' writing apparently without using the rubric of personal recount writing assessment agreed upon by the experts. He only judges based on the number of sentences and paragraphs written by students. The more writings, the better the score. This cannot be justified because the writing assessment must follow the rubric of the personal recount text assessment. In fact, in terms of students' writing, their writing still needs improvement. This is not in accordance with the writing stages where the writing process starts from the initial draft, the revision, and editing stages to produce the appropriate writing. This condition also does not educate them to be creative and critical in expressing their ideas in the right written text. This statement is supported by Oshima \& Hogue (2006) which states that writing is a process from pouring ideas in the form of initial drafts to improving writing through revision and editing to be better.

In addition, the 2013 curriculum book also recommends students to respond to peers at the writing stage. Students must work with their colleagues to evaluate their work with each other. It also provides aspects of writing what students must evaluate with the guidance of the teacher. This means that guided peer review can be used as alternatives in evaluating students' writing.

Based on the facts above, surely a solution is needed to overcome them. Therefore, a guided peer review is needed. This is defined as students taking a role in commenting and criticizing the draft writing of their peers in the writing process that is usually done by teachers in the classroom both in written and oral form (Liu and Hansen, 2002). In this study, the teacher does not release the students in full but still provided guidance in the initial 
stages of how to comment and revise their draft based on the input provided and provide students with a rubric that guides them how to use guided peer review appropriately. Specific objectives in this study include analyzing the difficulties so far faced by high school students in writing personal recount written text and analyzing students' ability to write personal recount texts using guided peer reviews. Therefore, guided peer review really needs to be done, further researched to provide solutions to this problem, and improve the quality of education in our country.

The researcher tries to implement this technique in SMA Plus Al Amanah, especially class $\mathrm{X}$ or 10 . The students in this school are chosen because the researcher believes their personal recount texts still have the problems and also the result of the interview with them indicate they have problems in writing class. To confirm about the problems, the researcher conducts preliminary study in this class. The result is only 4 students (13\%) who get score 70 or higher. It means that most of them still are not able to write personal recount well. The result of it can be the indicator to determine the class whether it has the problem or not. The researcher expects that the result of conducting this research will lead the students to write better. The criteria of success in this research at least $75 \%$ students get score 70 or higher.

Based on the above research background, the research questions are formulated as follows, 1) How is the process of implementing guided peer review? 2) What difficulties do the students have in writing personal recount written text? 3)What is the ability of students in writing personal recount texts after using guided peer review?

\section{METHOD}

The purpose of this study is to analyze the difficulties that have been faced by high school students in writing personal recount written text and analyze the improvement of students' ability to write personal recount texts using guided peer reviews in learning English in school. In this study, researchers used a collaborative classroom action research approach to improve the quality of education, especially teaching personal recount texts through the analysis of problems faced by students. Therefore, this research is deemed necessary to do. Classroom action research is a planned and systematic procedure for obtaining information about problems faced, ways to improve teaching and how students learn by teachers or other individuals related to education including researchers (Mills, 2011). In this case, researchers improve the quality of education based on the problems faced, reflect on these problems, collect and analyze data and implement changes based on findings in the field. Classroom action research or dialectic action research spiral aims to improve the quality of education (Schmuck, 1997). The model used is a kind of "spiral" because it uses four stages which include developing an action plan, identifying an area of focus, collecting data, analyzing and interpreting data. Then, repeating plans or re-planning, in order to get the expected results. 


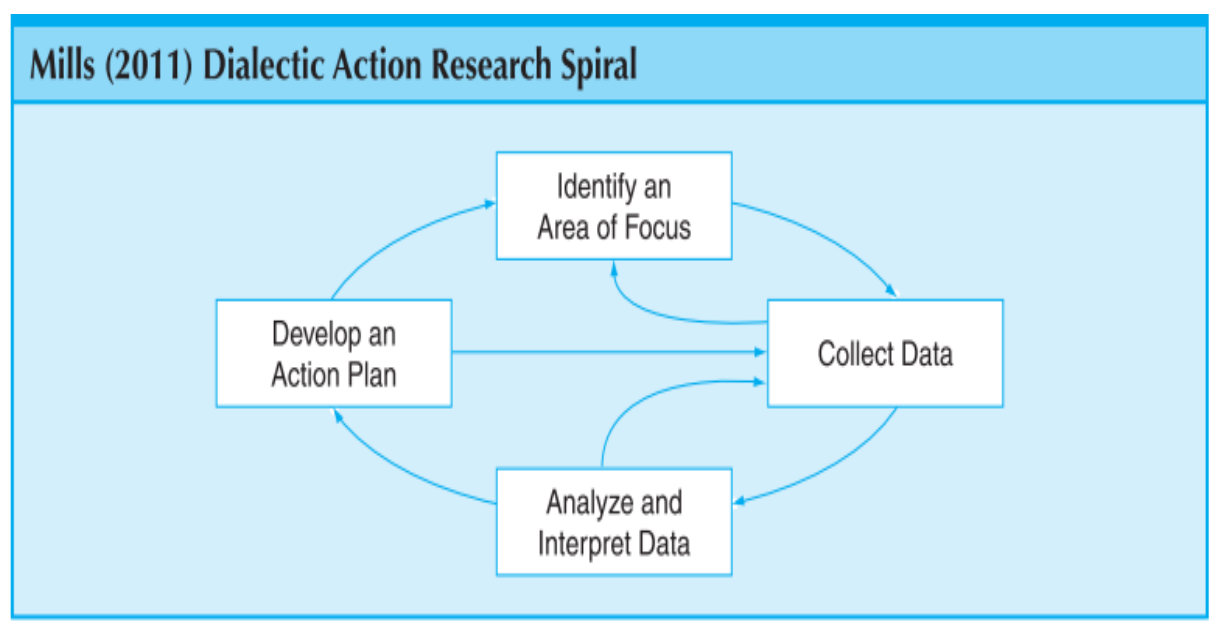

Picture 1. Dialectic Action Research Spiral

The research subjects in this study were high school class $\mathrm{X}$ or 10 students who were studying in Bojonegoro Regency. The data source in this study was taken from SMA Plus Al Amanah in Bojonegoro Regency with the consideration that the school has heterogeneous students.

In this study, the researcher used spiral dialectic action research proposed by Mills. At the development stage of planning, researchers prepare research instruments such as field notes, and video recorders to record the activities of students which is useful for analyzing the obstacles they face in writing personal recount texts. Researchers taught generic structure or language structure and language features or personal recount text that were useful so that students were able to write personal recount texts correctly. At the stage of identifying the focus area to be studied, the researcher focused on analyzing the constraints of the student's initial draft (before guided peer review implemented) about its generic structure and language features which were spelled out in the writing skills component including content, organization, vocabulary, language use and mechanics as well interviewing the difficulties encountered in writing personal recount written text. At the data collection stage, researchers applied guided peer review to address the problems faced by students from the initial draft of their writing. Finally, at the stage of analyzing and interpreting data, the researcher analyzed and compared the initial draft of students' writing and the draft that had been given input through guided peer review (final draft). At this stage, the researcher analyzed whether the score reached minimum score which was determined or not. If it did not, the researcher held next cycle.

The personal recount written text of the students in this study consisted of an initial draft (before guided peer review implemented) and a final draft (after guided peer review implemented) given by his peer. Personal recount written text components related to content, organization, vocabulary, language use and mechanics were analyzed and assessed using the ESL Composition Profile or personal recount written text grading rubric agreed upon by English linguists to find out to what extent guided peer review can increase the ability students in writing personal recount texts

\section{RESULT AND DISCUSSION}

The Process of Implementing Guided Peer Review

There were two research results covering the process of guided peer review activities and the score of students in 
writing personal recount texts. Difficulties of students and increasing student scores in writing personal recount texts using guided peer reviews were explained as follows:

\section{Data were collected in two cycles during the study \\ In each cycle, data was collected through the following stages:}

\section{Cycle 1}

Cycle 1 was conducted in four meetings. The first meeting was on May 11, 2019, the second meeting on May 14, 2019 and the third meeting on May 16, 2019, the fourth meeting on May 18, 2019. Here also presented an action plan, implementation, observation and reflection.

\section{The Development an Action Plan}

The planning phase was carried out on May 11, 2019. After the problem had been identified by the preliminary study, an action plan was carried out to improve the current situation. First of all, the teacher prepared lesson plans that include core competence, standard competence, indicators, assessments, time allocation and media. The indicator of this research was students are able to write personal recount texts correctly. Second, the teacher and collaborator prepared material so that students were able to write about the activities carried out yesterday. Third, he divided the class into groups. The students were divided into 15 groups; 2 students in each group. Heterogeneous group members were based on their achievements in preliminary studies. This meant that a group consisted of students above average and below average.

\section{Phase Identifies the Focus Area (Identify an Area of Focus)}

After planning, the teacher conducted several activities in teaching students about the personal recount text on May 14, 2019. First, the teacher taught his students the definition, generic structure and language features of the personal recount text. Then, he reminded them to write a personal recount text based on that. To make them understand well, he also gave them examples of corresponding personal recount texts.

Second, he asked observers to sit in the back row. Then, he began to explain the procedure of guided peer review. He also showed the first and second guided peer review sheets. The first guided peer review sheet focused on content and organization. Meanwhile, the second guided peer review sheet focused on vocabulary, language use, and mechanics. Then, he also taught his students how to respond in the pages. After everything's settled, the teacher proceeded to the discovery stage.

\section{Data Collection Stage (Collect Data)}

The data collection stage was divided into three stages, namely the discovery stage, the revision stage and the editing stage.

\section{Discovery Phase}

The teacher and collaborator determined the title of personal recount text. Then, the teacher asked them to write personal recount texts.

\section{Revision Phase}

On May 16, 2019, the teacher continued activities in data collection. The teacher asked students to share their writing with their colleagues in the group. Then, the teacher distributed guided peer review sheets, which consist of the strengths and weaknesses of their writing in terms of content and organization. After they finished giving responses on the first guided peer review sheet, the teacher asked them to give the first guided peer review 
sheet and the initial draft back to the owner. The teacher asked them to revise their writing based on the responses given in the first guided peer review sheet.

\section{Editing Stage}

After revising their writing, the teacher asked them to give a revised draft to their colleague next to him. He also asked one of the students to read his writing while his friends followed the revised draft in the group. After reading, the other group members did the same thing in turn. Then, the teacher distributes the second guided peer review sheet and asked them to provide responses to vocabulary, language use, and mechanics. After they finished responding, the teacher asked them to give the second guided peer review sheet and revised draft back to the owner. Finally, the teacher asked them to edit their writing based on the responses given in the guided peer review sheet to be the final draft. Then, proceed with the observation stage.

\section{Stage Analyze and Interpret Data (Analyze and Interpret Data)}

Observation was an activity to collect notes and documents from each indicator or aspect of interaction that occured in the teaching and learning process. At this stage, the collaborator also had the task to become an observer, monitor the implementation of guided peer review using the observation checklist. $\mathrm{He}$ observed whether the implementation met the success criteria or not.

The instrument used was observation checklist and test. Observation checklists were needed to observe the activities of teachers and students in the teaching and learning process and also needed to make lesson plans for the next cycle. Meanwhile, tests were needed to evaluate the ability of students in writing personal recount texts by assessing students' initial and final drafts. That was done at the end of each cycle.

The observer evaluated the process assessment and product assessment on May 18, 2019. He observes the activities of the teacher and students in the acting phase while the product assessment is taken after the teaching and learning process as an exam. The teacher and the observer interpret the data to decide whether the action taken was successful or not. If that doesn't work, the teacher will decide on a new plan for the next cycle in the hope that the next cycle is a better outcome than the previous one. Overall, the value of students has not yet reached the established criteria. They still have difficulty in writing personal recount texts both in terms of content and language use. Therefore, the next cycle needs to be done.

\section{Cycle 2}

Cycle 2 was carried out in four meetings. The first meeting was on May 20, 2019 and the second meeting on May 21, 2019, the third meeting on May 23, 2019, the fourth meeting on May 25, 2019. He also presented planning, implementing the use of guided peer reviews in writing personal recounts in two meetings, analyzed and interpreted.

\section{The Development an Action Plan}

Planning was carried out on May 20, 2019. First, researchers and collaborators discussed the preparation of an action plan. They discussed lesson plan in cycle 2 . Second, preparing the lessonplan and setting arrangement.

\section{Phase Identifies the Focus Area (Identify an Area of Focus)}

The acting phase was carried out on May 21, 2019. First of all, the teacher asked the observer to sit in the back row. Then, he taught his students the definition, generic 
structure and features of the personal recount text language. After everything's settled, he gave an example of the corresponding personal recount text. The teacher displayed the concepts and examples of personal recount texts with the LCD projector and explains them in detail.

Next, the teacher reviewed how to respond to the writing of their peers. $\mathrm{He}$ explained an example of an operational response to revise the writing of their colleague. He also took examples of students' responses to the writing of their peers, explaining and correcting errors in giving responses. To make students understand well, the teacher also gave appropriate examples of how to respond, revised and edited their draft based on the responses given by showing them the video of guided peer review. After everything was explained clearly, he went to the discovery stage

\section{Stage of Collecting Data (Collect Data) \\ Discovery}

The teacher instructed them to bring their picture in unforgetable moment to help them wrote the personal recount texts. The students took pieces of papers and began writing individually. The teacher always moved to help students overcome their difficulties in writing. At the end of the class, the teacher asked students to submit their writing.

\section{Revision Phase}

On May 23, 2019, the teacher asked students to share their initial drafts with their friends. The teacher reminded them to give operational comments and suggestions. They meant the comments and suggestions should be able to be understood by their peer what parts should be developed and organized for their writings. The teacher also reminded them by showing the operational comments and suggestions on LCD Projectors to make them understood. The teacher moved to guide them in giving an appropriate response. After they responded to all their colleagues in a group, they gave the first guided peer review sheet and a rough draft back to the owner. Then, they revised their initial draft. In this case, they tried to develop their writing. After they finished revising, the teacher distributed the second guided peer review sheet.

\section{Editing Stage}

Students exchanged their revised drafts with their colleagues in the group. The teacher reminded them to write lines and paragraphs that must be edited so that their friends found their mistakes. He also took the mistakes made by students in the second guided peer review sheet and corrected them. Then, they began to give responses on the second guided peer review sheet. After they responded to their colleague's mistakes, they returned the second guided peer review sheet and revised the draft back to the owner. Finally, they edited their revised drafts based on the recommendation of their colleague. After that, they wrote it into the final draft.

\section{Stage Analyze and Interpret Data (Analyze and Interpret Data)}

Observers gathered information from the activities of the teacher and students during the acting phase by using an observation list. He observed whether students do the activities written in the observation list or not by checking the yes or no column. This tool provides information about changes in how well students understood and used peer response techniques correctly. $\mathrm{He}$ also collected students' writing tests and ensures that the number of articles collected showed the same number of students present in class. 
Finally, he saved initial drafts and the final drafts of the students.

Researchers and collaborators conducted reflections that focus on the analysis of teaching and learning processes and students' writing results on May 25, 2019. In this cycle, students provided a significant improvement both in the teaching and learning process and the results of students. The students were very good in providing operational responses. This allowed their colleagues to revise their writing well. The final result, students' scores increased and reached a predetermined standard score.

In this study, the students are taught how to use guided peer review technique before students comment on the writing of their peers. This is in line to Fei's (2009) claim that peer review is not effective to be applied to students in China because they are not taught how to review the written texts of their peers. By teaching them how to use it, they know what they should do to comment their peer's personal recount texts. Teaching them how to use it is very important to make them understand how use it properly. They are also able to give operational comment and suggestion to make their peer writing better. This also reinforces the opinion of Prabasiwi (2017) providing an exception that peer review is indeed not effectively applied to students who have low motivation but is very effectively applied to students who have high motivation. The students who have high motivation feel enthusiastics to give comments to their peers and also provide the suggestion to make their peers writing better. In addition, students are able to develop and improve their writing using guided peer review.

\section{The Students' Problems in Writing Personal Recount Texts}

Researchers found that students had difficulty in writing personal recount texts. This could be proven by the score obtained in the initial draft of 5.40. The lowest score was 3.00 while the highest score was 7.50. To explain what components students had difficulty in writing personal recount texts, an analysis of five components was carried out namely content, organization, language use, vocabulary and mechanics. From the results of the analysis, the results could be described as follows:

\section{Content}

In cycle 1, students still had difficulty in composing personal recount texts. This could be proven by the average initial draft score of 8 (on a scale of 4,8 , 12 , and 16) which meant students were only able to tell limited events in personal recount texts. The score obtained was only 8. Researchers analyzed the ability of students in writing personal recount texts, especially in content, still needed to be improved. Students were only able to write briefly and did not elaborate what activities were explored in writing personal recount texts.

\section{Organization}

In cycle 1 , students had difficulty in arrranging the organization of their writing. This could be proven from the average initial draft score of 6 with a scale $(12,9,6$, $3)$. Researchers analyzed the difficulties of students in arranging personal recount texts because they did not know how to arrange the correct sequence of personal recount texts. Although, the organization was not coherent, the readers are still able to understand the organization of their writing. 


\section{Language use}

In cycle 1, the tense used in the personal recount text was simple past tense. However, students had many mistakes in terms of using past tense. They sometimes switched to use simple present tense in their writing. The average score of a student's initial draft was 2 with a scale $(1,2,3$, and 4). In addition, teachers did not provide adequate training on how to edit their writing.

\section{Vocabulary}

In cycle 1 , students made a few sentences to prepare their initial draft. Their personal recount text was not complicated in this cycle but they couldnot use it properly. Even though they could use the right vocabulary, some of them still make mistakes. The error was caused by students who forgot in spelling their words. The average score of their initial draft is 2 . Overall, their vocabularies were understandable.

\section{Mechanics}

In cycle 1 , they were still confused how to use mechanics in their writing because the teacher had never taught him in the daily teaching and learning process. They also assumed that mechanics was not important in the writing element so they ignored it. Their mechanical score in the first cycle was 2 with a scale $(1,2,3$, and 4). However, they were still able to use capital letters, full stops and comma in their writings. Overall, they still have problems in all components of writing in initial drafts in the first cycle.

\section{How the students' writings after using guided peer review}

To measure the contribution of guided peer reviews to students' personal recount writing, the researcher made a table of the score development of each cycle. Researchers wrote the average, lowest, highest score and mastery of class in writing personal recount text in each cycle. The table is as follows:

Tabel 1. The Students' Score and Percentage of the Class Mastery

Note: R1 = Initial drafts' Score

\begin{tabular}{lllll}
\hline & \multicolumn{3}{c}{ Cycle 1 } & \multicolumn{2}{c}{ Cycle 2 } \\
\cline { 2 - 5 } & \multicolumn{1}{c}{ R1 } & R2 & \multicolumn{1}{c}{ R1 } & R2 \\
\hline Average & 54 & 68.8 & 72 & 79.9 \\
Score Min & 30 & 50 & 50 & 62.5 \\
Score Max & 75 & 87.5 & 87.5 & 95 \\
Class Mastery & $20 \%$ & $53 \%$ & $63 \%$ & $83 \%$ \\
\hline
\end{tabular}

$\mathrm{R} 2=$ Final drafts' Score

Based on the table above, it showed that the ability of students in writing personal recount texts when they were in first cycle. The lowest score was 30 while the highest score was 75 . The average value of the class for the first time writing personal recount text was 54 and students who got score 70 or above were $20 \%$. In this case the students' initial ability to write personal recount texts was understood. The teacher showed a video on how to give a written response to a friend and respond to it. In this case, students became aware of how to do guided peer review. The difficulties experienced by students in writing personal recount texts could be seen in developing ideas and also about the use of simple past tenses. This was also reinforced by the results of students' interviews about the obstacles in writing personal recount texts.

After having guided peer review, the students' writing ability in the personal recount text increased. The lowest value 
was 5.00 while the highest value was 8.75 . The average score was 6.88 and class mastery was $53 \%$. In this case the students' ability to write personal recount texts after the guided peer review application was understood. But their score obtained had not reached the criteria of success.

In the second cycle, the lowest score of personal recount text was 50 and the highest score was 87.5. The average score was 72 and class mastery was $63 \%$. In this case the students' ability to write personal recount texts still did not reach the criteria of success.

After applying guided peer review, the lowest score was 62.5 and the highest score was 95 . The average score was 79.9 and class mastery was $83 \%$. In this case, the students' ability to write personal recount texts had reached criteria of success. Learners understand well how to respond to their friend's personal recount written text with the help of a teacher. The teacher guided them how to respond to their friends' writing in using guided peer review. The teacher also helped students in writing personal recount texts using a checklist to facilitate their mentoring.

This also reinforces research conducted by Mawlawi Diab (2010) showing that students in groups using guided peer review succeeded in correcting more errors than students in groups using self-assessment. This method has been proven to be very effective as research conducted by Yusof, Manan, \& Ahikin (2011) shows that students are able to provide constructive input to the writing of their peer if this method is used correctly and is useful to improve the quality of their writing. In addition, Kelly (2015) finds the results of guided peer review makes the reviewer focus on providing input to the text either in the form of revisions or editing so that the written text becomes better than the initial draft and is suitable for students who have problems writing text. In conclusion, guided peer review has positif impact to the students' personal recount texts.

\section{CONCLUSION}

The students still have problems in all components of writing in initial drafts. However, their writings are better after implementing guided peer review. It can be proved by the improvement of the students class mastery of final draft from the first to second cycles. They are 53\% and 83\% students reach the minimum score criteria. Operational comments and suggestions help their peer to develop their writing better. In this case, the guidance of teacher to show them how to give operational comments and suggestions are needed to make their peer are able to revise and edit their writing better.

In conclusion, guided peer review is able to be used in teaching writing on personal recount texts and improve the students writing skill in pesonal recount texts.

\section{REFERENCES}

Fei, H. (2009). Students' perceptions of peer response activity in English writing instruction. Teaching English in China, 4, 48-52.

Kelly, L. (2015). Effectiveness of guided peer review of student essays in a large undergraduate biology course. International Journal of Teaching and Learning in Higher Education, 27, 56-68.

Liu, J., \& Hansen, J. (2002). Peer response in second language writing classrooms. Ann Arbor, MI: University of Michigan Press.

Mawlawi-Diab, N. (2010). Effects of peerversus self-editing on students' revision of language errors in revised drafts. System: An International 
Fatoni, An Analysis of Guided.....73

Journal of Educational Technology and Applied Linguistics, 1, 85-95.

Mills, G. E. (2011). Action research: A guide for the teacher researcher (with MyEducationLab). (4th ed.). Upper Saddle River, NJ: Pearson/Allyn \& Bacon.

Oshima, A. \& Hogue, A. (2006). Writing academic english. New York: Pearson Longman.

Prabasiwi, E. A. \& Warsono. (2017). Employing self and peer editing techniques to teach writing recount texts for students with high and low motivation. English Education Journal, 7, 220-226.

Schmuck, R. A. (1997). Practical action research for change. Arlington Heights, IL: IRI/SkyLight Training and Publishing.

Yusof, J., Manan, Ab., \& Ahikin, N. (2011). Guided peer feedback on academic writing tasks using facebook notes: An exploratory study. Procedia - Social and Behavioral Sciences 67 (2011) 216 228. 